\title{
Protective effect of tea against lead and cadmium-induced oxidative stress-a review
}

\author{
Anna Winiarska-Mieczan $(\mathbb{B}$
}

Received: 19 September 2018/ Accepted: 28 September 2018/Published online: 13 October 2018

(C) The Author(s) 2018

\begin{abstract}
Exposure to $\mathrm{Cd}$ and $\mathrm{Pb}$ reduces the activity of antioxidant enzymes, which points to a decrease in the antioxidant potential of the body as a result of supplying factors which enhance cellular oxidation processes. Man is exposed to the effects of toxic metals because they are present in the environment, including in food. Since no effective ways to reduce the concentrations of $\mathrm{Cd}$ an $\mathrm{Pb}$ in food exist, studies are undertaken to develop methods of reducing their toxic effect on the body through chelating these metals using nutrients (which reduces their absorption by tissues) or increasing the oxidative capacity of the body (which decreases the possibility of inducing oxidative damage to internal organs). Studies performed on laboratory animals have shown that the use of tea infusions fulfil both functions.
\end{abstract}

Keywords Tea $\cdot$ Antioxidants $\cdot$ Protective effect $\cdot$ Oxidative stress $\cdot$ Cadmium $\cdot$ Lead

\footnotetext{
A. Winiarska-Mieczan ( $\square)$

Department of Bromatology and Food Physiology,

University of Life Sciences in Lublin, Akademicka 13,

20-950 Lublin, Poland

e-mail: anna.mieczan@up.lublin.pl
}

\section{Introduction}

The presence of toxic metals in food products has become a global problem. The most significant source of toxic metals for man is food of plant origin, and in particular cereals (EFSA 2012a, b), mostly due to the fact that they are the basis of nourishment throughout the world and are consumed most abundantly. Although, according to reference literature, the content of $\mathrm{Cd}$ and $\mathrm{Pb}$ in food normally does not exceed standard levels, due to the fact that these metals are capable of accumulating in tissues and have a long half-life (Winiarska-Mieczan 2014), their regular supply, even in small amounts, is dangerous. In 2012 EFSA reduced the tolerable intake level for $\mathrm{Cd}$ and $\mathrm{Pb}$. The TWI (Tolerable Weekly Intake) for $\mathrm{Cd}$ was determined at the level of $2.5 \mu \mathrm{g} / \mathrm{kg}$ of body weight/ week $(0.36 \mu \mathrm{g} / \mathrm{kg}$ of body weight/day) (EFSA 2012a), whereas the BMDL (Benchmark Dose Lower Confidence Limit) for $\mathrm{Pb}$ was: BMDL01 $0.5 \mu \mathrm{g} / \mathrm{kg}$ of body weight/day in children and BMDL01-1.5 $\mu \mathrm{g} / \mathrm{kg}$ of body weight/day and BMDL10 $0.63 \mu \mathrm{g} / \mathrm{kg}$ of body weight/day in adults (EFSA 2012b).

The studies point to three main reasons for toxicity of metals: (1) the ability to react directly with proteins which results from an affinity between metals and thiol, histidine and carboxyl groups and leads to attachment of metal ions to active sites of enzymes, structural elements of cells and proteins involved in cell transport (Rubino 2015); (2) replacement of 
elements necessary for metabolism, e.g. calcium in bones or iron in erythrocytes with metals, which leads to damage and changes in their structure and metabolism (Puerto-Parejo et al. 2017; Jaishankar et al. 2014; Cailliatte et al. 2009); (3) participation of metals in enhancing the production of reactive forms of oxygen and modification of the activity of the antioxidant system (Mao et al. 2018; Tandon et al. 2003).

No effective methods for reducing the concentration of $\mathrm{Cd}$ and $\mathrm{Pb}$ in food exist, therefore man is constantly exposed to the intake of these metals. However, studies are being undertaken to develop methods of reducing the toxic effect of $\mathrm{Cd}$ and $\mathrm{Pb}$ on the organism through chelating these metals using nutrients (which reduces their absorption by tissues) or increasing the oxidative capacity of the body (which decreases the possibility of inducing oxidative damage to internal organs). So far, for instance, vitamin $\mathrm{E}$, vitamin $\mathrm{C}$, rutin and curcumin have been found to have a positive effect (Al-Attar 2011; Mirani et al. 2012; Tarasub et al. 2012). From a practical nutritional point of view it is important to examine food products containing significant amounts of antioxidant components in order to use them in a daily diet to prevent the hazardous effect of toxic metals on the human body. In available literature positive effects have been reported, among other things, for garlic, honey, rosemary and green tea (Abdel-Moneim and Ghafeer 2007; El Kader et al. 2012; Hamed et al. 2010; Padalko et al. 2012). Tea, as the most popular drink in the world apart from water, deserves particular attention (Hicks 2009). Tea contains a number of substances with an antioxidant effect such as, for example, tannic acid (Savolainen 1992), catechins (Zaveri 2006) and quercetin (Chen et al. 2009). This paper analyzes the results of surveys referring to the protective effects of tea and antioxidants it contains on organisms exposed to $\mathrm{Pb}$ and $\mathrm{Cd}$.

\section{Pro-oxidant effect of $\mathrm{Cd}$ and $\mathrm{Pb}$}

Disorders of homeostasis leading to increased stationary concentrations of reactive forms of oxygen are referred to as oxidative stress. Oxidative stress induced by heavy metals can reduce the capacity of the antioxidant defence system, though lead and cadmium do not directly participate in producing reactive forms of oxygen. However, the organisms of experimental animals and people, who in their working environment were exposed to metals, showed a decrease in the resources of antioxidant vitamins (Adonaylo and Oteiza 1999; Skoczyńska 1997; Stohs and Bagchi 1995) and in the activity of endogenous antioxidant enzymes (Tandon et al. 2003) and endogenous non-enzymatic antioxidants (Mao et al. 2018). Cadmium and lead indirectly contribute to oxidative stress, secondarily leading to increased peroxidation of lipids, damage to nucleic acids, alterations in the expressions of genes and apoptosis processes, inhibiting the activity of antioxidant proteins by binding them to sulfhydryl groups and inhibiting calcium homeostasis (Czeczot et al. 2009; Fowler et al. 2004; Ercal et al. 2001; Stohs and Bagchi 1995). Their participation in creating free oxygen radicals and their derivatives is not only manifested in a disturbed flow of electrons in the respiratory chain, but also in the release of transition metals involved in the Fenton and Haber-Weiss reactions-mainly $\mathrm{Fe}(\mathrm{II})$ and $\mathrm{Cu}(\mathrm{I})$ from the sites in which they occur in cells (e.g. ferritine, ceruloplasmin, proteins containing ironsulphur clusters in the respiratory chain, heme proteins and other) (Stohs and Bagchi 1995; Waisberg et al. 2003; Valko et al. 2006). A higher amount of reactive forms of oxygen in cells exposed to the effect of toxic metals can also be a result of the deteriorated function of antioxidant mechanisms. This is mostly due to the decreased concentration of reduced glutathione (GSH) in cells, total pool of protein-bound - $\mathrm{SH}$ groups and changes in the activity of antioxidant enzymes (Nemmiche 2017).

Reactive oxygen species include one- (superoxide anion radical $\mathrm{O}_{2}^{-}$), two- (hydrogen peroxide $\mathrm{H}_{2} \mathrm{O}_{2}$ ) and three-electron (hydroxyl radical HO-) products of oxygen reduction and singlet oxygen, as well as ozone $\left(\mathrm{O}_{3}\right)$ or organic free radicals $(\mathrm{Wu}$ et al. 2011). The presence of reactive oxygen species in cells can lead to oxidative damage to antioxidant enzymes. For instance, these include catalase the activity of which is inhibited directly by $\mathrm{O}_{2}^{--}$(Kono and Fridovich 1982) or superoxide dismutase which in turn is inactivated by peroxynitrite (MacMillan-Crow et al. 1998). A secondary effect of changes in the structure of these enzymes can be an increase in the pool of $\mathrm{H}_{2} \mathrm{O}_{2}$ and $\mathrm{O}_{2}^{--}$in cells, which was demonstrated in studies on plant cells (Schützendübel and Polle 2002). Reactive oxygen species react with polyunsaturated fatty acids 
in cell membranes, which initiates the process of lipid peroxidation resulting in the modification of proteins, changes in the electrochemical gradient, which in turn gives rise to a loss of their integrity and to irreversible damage (Lambert and Elias 2010). If an unpaired electron is present, such molecules are characterized by high reactivity since they aim at pairing the electrons by accepting or giving them away. Given the current status of knowledge the mechanism of $\mathrm{Cd}$ an $\mathrm{Pb}$ toxicity involves inducing oxidative stress in cells, which results in the first place in peroxidative damage to cell membranes (Lambert and Elias 2010).

Cytotoxicity of heavy metals is limited by antioxidant enzymes such as superoxide dismutase (SOD), catalase (CAT) and glutathione peroxidase (GPX), converting oxygen species into molecular oxygen and water (Pourahmad and O'Brien 2000; Valko et al. 2006) and by non-enzymatic antioxidants occurring in cells, and in particular glutathione (GSH) (Pereira et al. 2013; Valko et al. 2006).

\section{Endogenous antioxidant mechanisms}

In the course of evolution all living organisms developed a number of enzymatic and non-enzymatic defence mechanisms tasked with maintaining reactive oxygen species at a low level safe to cells. Their main task is neutralizing free radicals, inhibiting free radical chain reactions and protecting the cell against their toxic effect (Liczmański 1988). The most important defence mechanisms of the body are connected with the antioxidant effect of SOD, CAT, GPX and GST (glutathione transferase). Short-term exposure to toxic metals enhances the activity of SOD, CAT, GPX and glutathione reductase, which points to the activation of defence mechanisms and adaptive response of the cells. When the exposure lasts longer, their activity in cells clearly decreases, which is a result of $\mathrm{Mn}, \mathrm{Cu}$ and/or $\mathrm{Zn}$ ions being displaced from the active site of MnSOD in the case of CuZnSOD or Fe ions from the heme group of catalase or Se ions from glutathione peroxidase (Dalle-Donne et al. 2008; Patra et al. 2011; Adi et al. 2016).

SOD is an enzyme occurring in cytosol (cytoplasmic matrix) and mitochondria. With regard to the type of metal present in the active site, three SOD classes can be distinguished: copper-zinc ( $\mathrm{Cu}, \mathrm{Zn}-\mathrm{SOD})$, manganese (Mn-SOD) and ferrous (Fe-SOD). This enzyme catalyzes the reaction of dismutation of superoxide anion radical $\left(\mathrm{O}_{2}^{--}\right)$producing hydrogen peroxide $\left(\mathrm{H}_{2} \mathrm{O}_{2}\right)$ and molecular oxygen $\left(\mathrm{O}_{2}\right)$ as a result of reduction and oxidation of metal ions forming a part of active sites of SOD. In peroxisomes, hydrogen peroxide is subject to further enzymatic dismutation to water and oxygen involving CAT. This compound is also a substrate for peroxidases which reduce it to water, oxidizing different compounds occurring in cells in reduced forms. In plants this is a role of ascorbate peroxidase occurring in chloroplasts and in cytoplasm and using ascorbate as a specific donor of electrons. This enzyme interacts with monodehydroascorbate reductase and dehydroascorbate reductase which regenerate ascorbate at the cost of oxidizing glutathione as well as with glutathione reductase which recreates the reduced glutathione in the reaction of oxidation of NADPH (Ighodaro and Akinloyeb 2017).

CAT is located in peroxisomes and is involved in inactivating $\mathrm{H}_{2} \mathrm{O}_{2}$ that is a side product of oxidation of fatty acids (Fujiwara et al. 2000). It is Fe-protoporphyrin composed of four monomers with heme group as the active site. CAT shows double activity: catalase and peroxidase activity. For high concentrations of hydrogen peroxide the basic function of the enzyme is its participation in a two-stage $\mathrm{H}_{2} \mathrm{O}_{2}$ disproportionation reaction. At the first stage, as a result of heme iron being oxidized by hydrogen peroxide, porphyrin cation radical is formed, whereas at the second stage the transitional reaction product is reduced to iron with oxidation state $3+$ by another molecule of hydrogen peroxide, as a result of which molecular oxygen and water are formed (Wołonciej et al. 2016).

GPX is a selenoenzyme acting as catalyst for the reduction of hydrogen peroxide by GSH. The reaction produces an oxidized form of glutathione (glutathione disulfide). GPX plays a significant role as a system of defence against reactive oxygen species; it protects both the cells and the extracellular area (Li et al. 2000). It participates in the first and second line of defence against free radicals. Glutathione peroxidase directs the attack of hydrogen peroxide onto glutathione preventing its participation in the Fenton reaction and thus protecting the thiol groups of proteins and reducing organic peroxides to alcohols ( $\mathrm{Li}$ et al. 2000). Eight forms of glutathione peroxidases were described-they occur in most internal organs and 
also in erythrocytes, cytosol, and mitochondrion and in the cell nucleus (Wołonciej et al. 2016).

GSH is a particulate sulfhydryl compound-an important non-enzymatic component of the antioxidant system of cells. In the cells it is not only an internal redox buffer, a direct "sweeper" of reactive oxygen species, but also a co-substrate in the reactions of inactivating reactive oxygen species and detoxicating the xenobiotics catalyzed by GSH-dependent enzymes (Dalle-Donne et al. 2008). Because GSH participates in direct binding of prooxidant metal ions, its total level in cells is reduced, which contributes to increased oxidative stress. The -SH glutathione group is much more accessible to oxygen than the thiol groups if enzymes. Therefore, GSH can secure biologically active proteins (Dalle-Donne et al. 2008).

\section{The antioxidant properties of tea}

Studies carried out by many authors have shown a high antioxidant potential of extracts of different types of tea (Awoniyi et al. 2011; Gawlik and Czajka 2007; Karori et al. 2007; Toschi et al. 2000). Consumption of teas intensifies the antioxidant capacity of the bodyit contributes to an increased activity of basic antioxidant enzymes such as: glutathione reductase, glutathione peroxidase, catalase, glutathione S-transferase and quinone reductase. It is mostly observed in the liver, small intestine and lungs (Michalak-Majewska 2011). It was demonstrated that the antioxidant potential in blood plasma after drinking green tea is increased by $34 \%$, while after drinking black tea the increase is $29 \%$ (Serafini et al. 1996). In vitro tests involving human erythrocyte preparations showed that green tea was characterized by higher antioxidant activity than white and black tea, which was evaluated based on the level of $\alpha$ - and $\gamma$ tocopherol in the analyzed cells (Gawlik and Czajka 2007). In turn, studies of a system simulating the process of oxidation occurring in the human body indicated that green and black tea infusions inhibited linoleic acid peroxidation very strongly and in a similar way (Wołosiak et al. 2008). Korir et al. (2014) presented similar results in their experiments involving mice. The results of clinical trials showed that green tea (single dose of $5 \mathrm{~g}$ extract/150 $\mathrm{ml}$ water) delays LDL oxidation (Ohmori et al. 2005). The LDL oxidation delay phase, measured by the amount of conjugated dienes, reaches the maximum $2 \mathrm{~h}$ after drinking tea. The protective effect of green tea on LDL is a result of an increase in the concentration of respective catechins in blood plasma, because the maximum concentration of catechins occurs $2 \mathrm{~h}$ after drinking tea, which coincides with the maximum of the LDL oxidation delay phase. Drinking green tea also increases the antioxidant activity of human blood plasma, depending on the dose (Sung et al. 2000). The overall antioxidant capacity after drinking 2 cups of tea $(1$ cup $=2.5 \mathrm{~g}$ leaves $/ 150 \mathrm{ml}$ water $)$ compared to water is $7 \%$ higher in $60 \mathrm{~min}$ and $6.2 \%$ higher in $120 \mathrm{~min}$. Increasing the dose to 3 cups of tea increases the antioxidant activity of plasma by $12 \%$ in $60 \mathrm{~min}$, whereas this activity remains unchanged for at least up to 120 min after drinking tea. In turn, Serafini et al. (1996) demonstrated that drinking $300 \mathrm{ml}$ of green tea increases the antioxidant capacity of blood plasma by $40 \%$ in $30 \mathrm{~min}$. However, even $80 \mathrm{~min}$ after consumption, this value reaches the baseline. Studies carried out by Ambrożewicz et al. (2010) revealed that black tea has an even stronger effect than green tea on the antioxidant system of the human umbilical vein endothelial cells under oxidative stress induced by tert-butyl hydroperoxide. In addition, infusions from both types of tea prevented oxidative modification of lipids and proteins to a significant extent.

It is believed that the antioxidant properties of tea result from the high content of polyphenols such as catechins (Zaveri 2006), including epigallocatechin-3gallate (EGCG) in green tea (Kim et al. 2014), quercetin (Chen et al. 2009), theaflavins and thearubigins in black tea (Gramza et al. 2005) and tannic acid (Savolainen 1992). Total polyphenols account for $25-35 \%$ of the dry matter of tea leaves (Bharadwaz and Bhattacharjee 2012). The highest total content of polyphenols (presented as an equivalent of tannic acid) is found in white tea $(2668 \mathrm{mg}$ per $1000 \mathrm{ml})$, followed by green tea $(2363 \mathrm{mg}$ per $1000 \mathrm{ml})$, black tea $(1220 \mathrm{mg}$ per $1000 \mathrm{ml})$ and red tea $(996 \mathrm{mg}$ per $1000 \mathrm{ml}$ ) (Winiarska-Mieczan 2015).

Catechins, believed to be the most important antioxidants in tea, were studied very thoroughly. They are colourless water-soluble substances which make the infusion taste bitter and have an astringent effect (Bharadwaz and Bhattacharjee 2012). Catechins account for $8-15 \%$ of the dry matter of tea leaves (Choung et al. 2013). Green tea, that is not subject to fermentation, contains more catechins than fermented 
teas such as oolong (partial fermentation) or black and $\mathrm{Pu}$-erh teas (complete fermentation) (Toschi et al. 2000). During fermentation of $\mathrm{O}_{2}$ oxidoreductase, involving polyphenol oxidase, monophenol monooxygenase and o-diphenol, about $75 \%$ of catechins contained in leaves are subject to enzymatic oxidation (Donejko et al. 2013; Kusano et al. 2015; Kuhnert 2010). The content and type of catechins in green tea depends on the variety of tea, climate and growing conditions (Toschi et al. 2000). Also, the conditions in which tea infusions are made have an impact on the content of catechins in the infusion. The most effective infusions are made at $80{ }^{\circ} \mathrm{C}$ for $40 \mathrm{~min}$ (Choung et al. 2013). In turn, infusions made at a temperature of about $100{ }^{\circ} \mathrm{C}$ have catechins content lower by even $15 \%$ (Gramza et al. 2005). Studies showed that in 60 min after drinking green tea, human blood plasma contains 3 times more catechins than after drinking black tea (Leenen et al. 2000). The predominant type of catechins found in tea infusions is EGCG (Fig. 1a), (Karori et al. 2007). In addition, epigallocatechin (EGC; Fig. 1b), epicatechin (EC; Fig. 1c) and epicatechin gallate (ECG) have a large share. The classic antioxidant effect of catechins is based on their reducing properties, including direct inactivation of reactive oxygen and nitrogen species and decreasing the production of reactive oxygen species, as well as an indirect effect being the regeneration of other antioxidants such as $\alpha$-tocopherol or $\beta$-carotene and chelating transitional metals (Kim et al. 2014; Abib et al. 2011). Studies involving rats as subjects revealed that EGCG had higher bioactivity than EGC and EC (Rietveld and Wiseman 2003). The condition for high antioxidant activity of EGCE is the presence of eight $\mathrm{OH}$ groups (Gramza et al. 2005). Young tea leaves contain EGCG $>$ EGC $>$ ECG $>$ EC, mature leaves $\mathrm{EGC}>\mathrm{EGCG}>\mathrm{ECG}>\mathrm{EC}$, whereas old ones $\mathrm{EGC}>\mathrm{EGCG}>\mathrm{EC}>\mathrm{ECG}$ (Karori et al. 2007). Studies by Xu et al. (2004) concerning the antioxidant activity of catechins present in green tea noted a considerable increase in the antioxidant potential of the blood plasma of rats after administration of an oral dose of a mixture of catechins in the amount of $4000 \mathrm{mg} / \mathrm{kg}$ of body weight. The maximum antioxidant activity was observed in the 40th min after administration of the mixture, which coincides with the maximum concentration of catechins in blood plasma in time.
Quercetin (Fig. 1d) is a phytocompound from a group of flavonoids of plant origin, demonstrating a wide range of properties, for instance antioxidant, anti-inflammatory and immunomodulating properties. Antioxidant properties of quercetin result from its ability to "sweep" reactive oxygen species, inhibiting the activity of enzymes participating in the creation of reactive oxygen species, such as oxidases, enzymes, with substrates such as, for instance, purine derivatives (e.g. kinases, ATPases, adenylyl cyclase, reverse transcriptase, DNA and RNA polymerases, ribonuclease) and enzymes using NADPH as a co-enzyme (e.g. aldose reductase, lactate dehydrogenase, nitric oxide synthase, glutathione reductase). Quercetin also shows the ability to modulate the activity of enzymes involved in antioxidant processes, e.g. SOD and GST (Dolinoy et al. 2006; Kobylińska and Janas 2015; El-Sayed and Rizk 2009). The antioxidant capacity of quercetin is closely connected with its chemical structure (possibility to give away an electron or hydrogen atom), thanks to which it can neutralize singlet oxygen $\left({ }^{1} \mathrm{O}_{2}\right)$, superoxide anion radical $\left(\mathrm{O}_{2}^{-}\right)$, hydroxyl radical $(\mathrm{OH})$, peroxyl radicals (LOO), nitrogen oxide (NO) and peroxynitrite (ONOO-) (Amorati et al. 2017; Amić et al. 2017; Dolinoy et al. 2006). The antioxidant activity of quercetin is also manifested in its ability to capture alkoxy radicals by giving away one $\mathrm{OH}$ electron, and stabilizing the resulting alkoxy radicals thanks to an aromatic ring (Dolinoy et al. 2006).

Black teas are dominated by theaflavins (Fig. 1e) and thearubigins (Fig. 1f), because during the process of fermentation of tea leaves catechins are condensed into larger polyphenol molecules (Wang et al. 2016). Theaflavins are formed at the first stage of fermentation. At the following stages oxidation products are transformed into thearubigins (Bailey et al. 1994; Kusano et al. 2015). So far at least 28 derivatives of theaflavin have been recognized. Theaflavin (TF1), theaflavin-3-gallate (TF2A), theaflavin- $3^{\prime}$-gallate (TF2B) and theaflavin-3,3'-digallate (TF3) are predominant in black tea. Studies of the antioxidant activity of teas clearly indicate that the activity of theaflavins and that of catechins is comparable. Theaflavin-3,3'-digallate in black tea shows antioxidant activity similar to that of EGCG in green tea extract (Karori et al. 2007; Wu et al. 2011; Yoshino et al. 1994). Studies showed effectiveness of theaflavins in reducing oxidation of human LDL as 
<smiles>O=C(O[C@H]1Cc2c(O)cc(O)cc2O[C@H]1c1cc(O)c(O)c(O)c1)c1cc(O)c(O)c(O)c1</smiles>

(a) Epigallocatechin-gallate EGCG<smiles>O=c1c(O)c(-c2ccc(O)c(O)c2)oc2cc(O)cc(O)c12</smiles>

(d) Quercetin

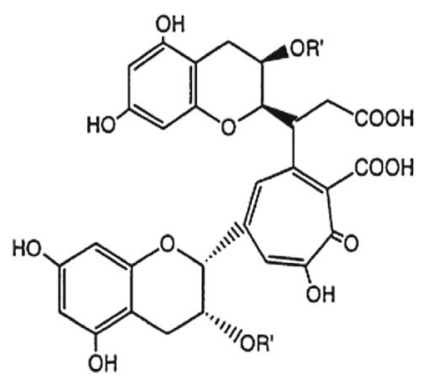

(f) Thearubigin<smiles>Oc1cc(O)c2c(c1)O[C@H](c1cc(O)c(O)c(O)c1)[C@H](O)C2</smiles>

(b) Epigallokatechin EGC<smiles>[R20][C@H]1Cc2c(O)cc(O)cc2O[C@H]1c1cc(O)c(=O)c2c(O)c(O)cc([C@@H]3Oc4cc(O)cc(O)c4C[C@H]3[R20])c2c1</smiles>

TF1: $\mathrm{R}_{1}=\mathrm{R}_{2}=\mathrm{H}$;

TF2A: $\mathrm{R}_{1}=$ galloyl, $\mathrm{R}_{2}=\mathrm{H}$; TF2B: $\mathrm{R}_{1}=\mathrm{H}, \mathrm{R}_{2}=$ galloyl; TF3: $\mathrm{R}_{1}=\mathrm{R}_{2}=$ galloyl

(e) Theaflavin<smiles>O=C(OCC1OC2OC(C1O)C(OC(=O)c1cc(O)c(O)c(O)c1)C(OC(=O)c1cc(O)c(O)c(O)c1)C2O)c1cc(O)c(O)c(OC(=O)c2cc(O)c(O)c(O)c2)c1</smiles>

(g) Tannic acid

Fig. 1 Chemical structure of some major polyphenols in tea

$\mathrm{TF} 3>\mathrm{ECG} \geq \mathrm{EGCG} \geq \mathrm{TF} 2 \mathrm{~B} \geq \mathrm{TF} 2 \mathrm{~A}>\mathrm{TF} 1 \geq$ $\mathrm{EC}>\mathrm{EGC}$ (Leung et al. 2001). Thearubigins, accounting for about $60 \%$ of polyphenolic compounds in black tea extract, are strongly oxidized polymeric polyphenolic fractions (Kuhnert 2010; Menet et al.
2004). Tests involving rats showed that both theaflavin and thearubigin are effective inhibitors of peroxidation in liver cells (Yoshino et al. 1994).

Tannins present in tea are a product of polyphenolic oxidation (Chung et al. 1998). According to Sánchez- 
Moreno et al. (2000), tannins are better antioxidants than other commonly used antioxidants such as vitamin C and E. Tannic acid (Fig. 1g) has very strong antioxidant properties. According to Pulido et al. (2000) tannic acid is characterised by a higher antioxidant capacity than other polyphenols and this capacity is not lower than that of BHA, BHT and $\alpha-$ Tocopherol (Gülcin et al. 2010). Tannic acid in in vitro conditions inhibits almost $98 \%$ of peroxidation of lipids at the concentration of $15 \mu \mathrm{g} / \mathrm{ml}$, while standard antioxidants (e.g. BHA and $\alpha$-Tocopherol) have similar results at the concentration of $45 \mu \mathrm{g} / \mathrm{ml}$. Tannic acid also demonstrates a comparable capability of chelating metals (Gülcin et al. 2010). Tannic acid is absorbed from the alimentary tract in mice and sheep, it is found in blood plasma (Zhu et al. 1992) and can have a chelating effect on toxic metals present in blood and internal organs. The highest content of tannic acid in $1000 \mathrm{ml}$ of tea infusion (prepared in distilled water at a temperature of $90^{\circ} \mathrm{C}$ for $5 \mathrm{~min}$ ) occurs in white and green tea (more than $110 \mathrm{mg}$ ), followed by black tea $(94 \mathrm{mg}$ ) and red tea $(77 \mathrm{mg}$ ) (Winiarska-Mieczan 2015).

It was demonstrated that a particularly high antioxidant capacity of green and white tea results from the fact that these teas do not differ significantly in terms of the content of total polyphenols, catechins and antioxidant activity (Karori et al. 2007).

\section{Protective effect of tea on organisms exposed to Cd and $\mathbf{P b}$}

Antioxidant effect

Exposure to $\mathrm{Cd}$ and $\mathrm{Pb}$ reduces the activity of antioxidant enzymes, which points to a decrease in the antioxidant potential of the body as a result of supplying agents enhancing cellular oxidation (Ramesh and Satakopan 2010; Wei and Meng 2011). The increase in the activity of SOD, CAT, GST and GPX and an increase in the content of GSH in the organs of animals (rats, chickens) receiving tea solutions (Tables 1, 2, 3), observed in numerous studies, indicates increased efficiency of antioxidant mechanisms resulting from the supply of exogenous antioxidants, which facilitates maintaining a balance in redox reactions and prevents oxidative stress (Fig. 2). Other studies revealed that the activity of endogenous antioxidant enzymes is increased as a result of supplying antioxidants only during long-term exposure to $\mathrm{Cd}$ and $\mathrm{Pb}$ (Winiarska-Mieczan 2013), which indicates that only regular, continuous drinking of tea ensures positive results. Also, other authors using tea demonstrated that it supports antioxidant processes in the body exposed to $\mathrm{Cd}$ and $\mathrm{Pb}$. El-Shahat et al. (2009) revealed that green tea extract administered to rats receiving $\mathrm{Cd}$ in the form of a water-based solution containing $0.4 \% \mathrm{CdCl}_{2}$ reduced the degree of peroxidation of lipids in testicles, thus preventing damage. According to Khalaf et al. (2012) green tea extract administered to rats poisoned with $\mathrm{Pb}$ in the amount of $100 \mathrm{mg} / \mathrm{kg}$ of body weight for 15 days increased the activity of antioxidant enzymes, including SOD, in the brain. According to studies by Hamed et al. (2010), Meki et al. (2011) and Abdel-Maneim et al. (2014), after using an extract of green tea in rats poisoned with a $0.4 \%$ lead acetate solution for 6 weeks, the activity of GST, SOD and the content of GSH in the brain, blood, liver and kidneys increased in comparison to the control group (water). In the quoted studies a reduction in the degree of peroxidation of lipids was found in the analyzed organs. Studies regarding the brain are particularly worth attention because this is an organ that is critical with regard to the toxic effect of $\mathrm{Cd}$ and $\mathrm{Pb}$. Prolonged exposure to $\mathrm{Cd}$ and $\mathrm{Pb}$ causes brain damage as a result of oxidative stress (Adonaylo and Oteiza 1999; Flora et al. 2008). This is due to its high consumption of oxygen, high content of lipids and relatively low content of antioxidant enzymes in the organ. Particularly significant alterations in the activity of antioxidant enzymes can be observed in the cerebral mitochondria, which are the main source of superoxide anion radical and hydrogen peroxide (Tian et al. 1998). The brains, lungs, hearts, livers and kidneys of rats poisoned simultaneously with $\mathrm{Cd}$ and $\mathrm{Pb}(7 \mathrm{mg} \mathrm{Cd}$ and $50 \mathrm{mg}$ $\mathrm{Pb} / \mathrm{kg}$ feed), drinking green, black, red and white tea, showed an increased activity of SOD, CAT and GPX and an increased level of GSH compared to the control group (Winiarska-Mieczan 2015). The effectiveness of teas increased along with the duration of the experiment (6 vs. 12 weeks). Also, Cd injected in rats with a water-based green tea solution (Hamden et al. 2009; Kumar et al. 2010a, b) significantly increased the activity of exogenous antioxidants in the blood and liver. 
Table 1 Effect of tea on an organism exposed to $\mathrm{Pb}$

\begin{tabular}{|c|c|c|c|c|c|}
\hline Tea & Protective effect & $\mathrm{Pb}$ dose and design & Animals & $\begin{array}{l}\text { Target } \\
\text { sites }\end{array}$ & References \\
\hline $\begin{array}{c}\text { Green } \\
\text { tea }\end{array}$ & $\begin{array}{l}\uparrow \mathrm{TAC} ; \uparrow \text { RGSH; } \uparrow \mathrm{SOD} ; \downarrow \text { DNA } \\
\text { fragmentation }\end{array}$ & $\begin{array}{l}100 \mathrm{mg} \text { of lead acetate } / \mathrm{kg} \text { bw by gastric tube } \\
\text { for } 1 \text { month; green tea in drinking water } \\
(5 \mathrm{~g} / \mathrm{l}) \text { orally for } 1 \mathrm{month}\end{array}$ & $\begin{array}{l}\text { Albino } \\
\text { male rats }\end{array}$ & Brain & $\begin{array}{l}\text { Khalaf et al. } \\
\text { (2012) }\end{array}$ \\
\hline $\begin{array}{c}\text { Green } \\
\text { tea }\end{array}$ & $\begin{array}{l}\uparrow \mathrm{GST} ; \uparrow \mathrm{RGSH} ; \uparrow \mathrm{SOD} ; \uparrow \mathrm{TAC} ; \\
\quad \downarrow \mathrm{LPO} ; \downarrow \mathrm{Pb}\end{array}$ & $\begin{array}{l}0.4 \% \text { aqueous solution of lead acetate orally } \\
\text { for } 6 \text { weeks; green tea in distilled water } \\
(15 \mathrm{~g} / \mathrm{l}) \text { orally for } 6 \text { weeks }\end{array}$ & Rats & $\begin{array}{l}\text { Brain, } \\
\text { blood }\end{array}$ & $\begin{array}{l}\text { Hamed et al. } \\
\text { (2010) }\end{array}$ \\
\hline $\begin{array}{c}\text { Green } \\
\text { tea }\end{array}$ & $\begin{array}{l}\uparrow \mathrm{SOD} ; \downarrow \text { LPO; } \uparrow \mathrm{GST} ; \downarrow \mathrm{Pb} \\
\text { accumulation }\end{array}$ & $\begin{array}{l}0.4 \% \text { aqueous solution of lead acetate orally } \\
\text { for } 6 \text { weeks; green tea in drinking water } \\
(15 \mathrm{~g} / \mathrm{l}) \text { orally for } 6 \text { weeks }\end{array}$ & Male rats & $\begin{array}{l}\text { Liver, } \\
\text { kidney, } \\
\text { brain }\end{array}$ & $\begin{array}{l}\text { Meki et al. } \\
\text { (2011) }\end{array}$ \\
\hline $\begin{array}{c}\text { Green } \\
\text { tea }\end{array}$ & $\begin{array}{l}\downarrow \text { LPO; } \uparrow \text { SOD; } \uparrow \text { GST; } \uparrow \text { GSH; } \downarrow \\
\text { LPO; } \downarrow \text { Pb accumulation; } \uparrow \text { urea } \\
\text { in blood; } \downarrow \text { creatinine in blood }\end{array}$ & $\begin{array}{l}0.4 \% \text { aqueous solution of lead acetate orally } \\
\text { for } 6 \text { weeks; green tea in drinking water } \\
(15 \mathrm{~g} / \mathrm{l}) \text { orally for } 6 \text { weeks or mixture of } \\
0.4 \% \mathrm{lead} \text { acetate }+ \text { green tea solution } \\
(15 \mathrm{~g} / \mathrm{l})\end{array}$ & $\begin{array}{l}\text { Male } \\
\text { Sprague- } \\
\text { Dawley } \\
\text { rats }\end{array}$ & Kidney & $\begin{array}{l}\text { Abdel- } \\
\text { Maneim } \\
\text { et al. }(2014)\end{array}$ \\
\hline $\begin{array}{c}\text { Green } \\
\text { tea }\end{array}$ & $\begin{array}{l}\downarrow \mathrm{ALT} ; \downarrow \text { AST } ; \downarrow \mathrm{TC} ; \downarrow \text { LDL; } \downarrow \\
\quad \mathrm{TG} ; \uparrow \mathrm{HDL}\end{array}$ & $\begin{array}{l}500 \mathrm{mg} \text { lead acetate } / \mathrm{kg} \text { diet daily for five } \\
\text { weeks; green tea extract }(882 \mathrm{mg} / \mathrm{kg} \\
\text { bw/day) orally injected for five weeks }\end{array}$ & $\begin{array}{l}\text { Male } \\
\text { albino } \\
\text { rats }\end{array}$ & Blood & $\begin{array}{l}\text { El-Ziney } \\
\text { et al. }(2017)\end{array}$ \\
\hline $\begin{array}{c}\text { Green } \\
\text { tea }\end{array}$ & $\begin{array}{l}\uparrow \text { total protein; } \uparrow \text { albumin; } \uparrow \\
\mathrm{SOD} ; \uparrow \mathrm{GST} ; \downarrow \text { AST; } \downarrow \text { ALT; } \downarrow \\
\mathrm{ALP} ; \downarrow \mathrm{Pb} \text { concentration in } \\
\text { liver }\end{array}$ & $\begin{array}{l}0.4 \% \text { aqueous solution of lead acetate orally } \\
\text { for } 30 \text { days; } 6.6 \% \text { green tea extract orally } \\
\text { for } 30 \text { days }\end{array}$ & $\begin{array}{l}\text { Male } \\
\text { Wistar } \\
\text { rats }\end{array}$ & $\begin{array}{l}\text { Liver, } \\
\text { blood }\end{array}$ & $\begin{array}{l}\text { Hamadouche } \\
\text { et al. (2014) }\end{array}$ \\
\hline $\begin{array}{c}\text { Green } \\
\text { tea }\end{array}$ & $\begin{array}{l}\downarrow \mathrm{MDA} ; \uparrow \mathrm{GSH} ; \uparrow \mathrm{SOD} ; \uparrow \mathrm{CAT} ; \\
\quad \downarrow \mathrm{Pb} \text { accumulation; }\end{array}$ & $\begin{array}{l}200 \mathrm{mg} \mathrm{Pb} \text { (as lead acetate)/kg basal diet for } \\
42 \text { days; } 1 \mathrm{~g} \text { green tea based probiotic } / \mathrm{kg} \\
\text { basal diet for } 42 \text { days }\end{array}$ & $\begin{array}{l}\text { Ross } \\
\text { broiler } \\
\text { chicks }\end{array}$ & $\begin{array}{l}\text { Liver, } \\
\text { blood }\end{array}$ & $\begin{array}{l}\text { Yosef et al. } \\
\text { (2012) }\end{array}$ \\
\hline $\begin{array}{c}\text { Green } \\
\text { tea }\end{array}$ & $\begin{array}{l}\downarrow \mathrm{Pb} \text { accumulation; } \downarrow \text { LPO; } \uparrow \\
\quad \mathrm{GSH} ; \uparrow \text { GST; } \uparrow \text { SOD }\end{array}$ & $\begin{array}{l}\text { Mixture of } 1.5 \text { green tea extract and } 0.4 \% \\
\text { lead acetate/l distilled water for } 6 \text { weeks }\end{array}$ & $\begin{array}{l}\text { Male } \\
\text { Sprague- } \\
\text { Dawley } \\
\text { rats }\end{array}$ & Testes & $\begin{array}{l}\text { Essa et al. } \\
\text { (2009) }\end{array}$ \\
\hline $\begin{array}{c}\text { Green } \\
\text { tea }\end{array}$ & $\begin{array}{l}\uparrow \text { total protein; } \uparrow \text { albumin; } \downarrow \text { AST; } \\
\downarrow \text { ALT; } \downarrow \text { ALP; } \downarrow \text { Pb } \\
\text { accumulation; } \uparrow \text { SOD; } \uparrow \text { GST }\end{array}$ & $\begin{array}{l}0.4 \% \text { aqueous solution of lead acetate orally } \\
\text { for } 8 \text { weeks; } 1.5 \% \text { green tea extract in } \\
\text { drinking water for } 8 \text { weeks }\end{array}$ & $\begin{array}{l}\text { Male } \\
\text { Sprague- } \\
\text { Dawley } \\
\text { rats }\end{array}$ & Liver & $\begin{array}{l}\text { Mehana et al. } \\
\text { (2012) }\end{array}$ \\
\hline $\begin{array}{c}\text { Green } \\
\text { tea }\end{array}$ & $\downarrow \mathrm{LPO} ; \uparrow \mathrm{CAT} ; \uparrow \mathrm{SOD} ; \uparrow \mathrm{GPX}$ & $\begin{array}{l}0.4 \% \text { aqueous solution of lead acetate orally } \\
\text { for } 4 \text { weeks; } 6.6 \% \text { green tea extract orally } \\
\text { for } 4 \text { weeks }\end{array}$ & $\begin{array}{l}\text { Male } \\
\text { Wistar } \\
\text { rats }\end{array}$ & Kidneys & $\begin{array}{l}\text { Hamadouche } \\
\text { et al. (2015) }\end{array}$ \\
\hline $\begin{array}{c}\text { Green } \\
\text { tea }\end{array}$ & $\downarrow \mathrm{MDA} ; \uparrow \mathrm{SOD} ; \uparrow \mathrm{GSH}$ & $\begin{array}{l}1 \mathrm{~g} / \mathrm{l} \text { drinking water lead acetate/day orally } \\
\text { for } 8 \text { weeks; } 1.5 \% \text { green tea extract orally } \\
\text { for } 8 \text { weeks }\end{array}$ & $\begin{array}{l}\text { Male } \\
\text { Sprague- } \\
\text { Dawley } \\
\text { rats }\end{array}$ & Testes & $\begin{array}{l}\text { El-Beltagy } \\
\text { et al. }(2015)\end{array}$ \\
\hline
\end{tabular}

$\uparrow$ increased concentration or activity compared to $\mathrm{Pb}$ group, $\downarrow$ decreased or inhibited concentration or activity compared to $\mathrm{Pb}$ group, $R G S H$ reduced glutathione, GSH glutathione, $S O D$ superoxide dismutase, $C A T$ catalase, $A L P$ alkaline phosphatase, $L P O$ lipid peroxidation, $T A C$ total antioxidant capacity, GPX glutathione peroxidase, GST glutathione S-transferase, $M D A$ malondialdehyde, $L D L$ low density lipoprotein, $H D L$ high-density lipoprotein, $T G$ triglicerides, $T C$ total cholesterol, $A L T$ alanine aminotransferase, $A S T$ aspartate aminotransferase, $b w$ body weight

Increased activity of endogenous antioxidant mechanisms in the bodies of animals poisoned with $\mathrm{Cd}$ and $\mathrm{Pb}$ was also observed when isolated antioxidants naturally occurring in tea were used (Table 4). Most studies refer to quercetin having a proven strong antioxidant effect (Dolinoy et al. 2006; Kobylińska and Janas 2015; El-Sayed and Rizk 2009). 75 mg of quercetin, administered orally to rats poisoned with 
Table 2 Effect of tea on an organism exposed to Cd

\begin{tabular}{|c|c|c|c|c|c|}
\hline Tea & $\begin{array}{l}\text { Protective effect compared } \\
\text { to Cd treated animals }\end{array}$ & Cd dose and design & Animals & $\begin{array}{l}\text { Target } \\
\text { sites }\end{array}$ & References \\
\hline Green tea & $\begin{array}{l}\uparrow \text { sugar; } \uparrow \text { protein; } \uparrow \text { ALP } ; \downarrow \\
\text { ACP } \downarrow \downarrow \text { ALT } ; \downarrow \text { AST }\end{array}$ & $\begin{array}{l}10 \mathrm{mg} \text { dose of cadmium chloride/kg bw by oral } \\
\text { route; green tea in drinking water ( } 20 \text { or } \\
40 \mathrm{mg} / \mathrm{kg} \mathrm{bw} \text { ) orally for } 15 \text { or } 30 \text { days }\end{array}$ & $\begin{array}{l}\text { Male } \\
\text { Wistar } \\
\text { rats }\end{array}$ & Liver & $\begin{array}{l}\text { Singh } \\
\text { et al. } \\
\text { (2013a) }\end{array}$ \\
\hline Green tea & $\begin{array}{l}\uparrow \mathrm{Hb} ; \uparrow \mathrm{RBC} ; \uparrow \mathrm{PCV} ; \uparrow \\
\mathrm{TLC} ; \uparrow \mathrm{MCV}\end{array}$ & $\begin{array}{l}10 \mathrm{mg} \text { dose of cadmium chloride/kg bw by oral } \\
\text { route; green tea in drinking water ( } 20 \text { or } \\
40 \mathrm{mg} / \mathrm{kg} \mathrm{bw} \text { ) orally for } 15 \text { or } 30 \text { days }\end{array}$ & $\begin{array}{l}\text { Male } \\
\text { Wistar } \\
\text { rats }\end{array}$ & Blood & $\begin{array}{l}\text { Singh } \\
\text { et al. } \\
(2013 b)\end{array}$ \\
\hline Green tea & $\begin{array}{l}\downarrow \text { LDL } ; \downarrow \text { GGT; } \downarrow \text { ACP } \downarrow \\
\text { ALP } \downarrow \downarrow \text { bilirubin; } \uparrow \text { SOD; } \uparrow \\
\text { CAT; } \uparrow \text { GPX; } \downarrow \text { TBARs }\end{array}$ & $\begin{array}{l}20 \mu \text { moles of cadmium } / \mathrm{kg} \text { bw/every } 3 \text { days for } \\
6 \text { months by injection; } 5 \% \text { green tea extract } \\
\text { in drinking water for } 12 \mathrm{~h} \text { daily during } \\
6 \text { months }\end{array}$ & $\begin{array}{l}\text { Male } \\
\text { Wistar } \\
\text { rats }\end{array}$ & $\begin{array}{l}\text { Liver, } \\
\text { blood }\end{array}$ & $\begin{array}{l}\text { Hamden } \\
\text { et al. } \\
(2009)\end{array}$ \\
\hline Green tea & $\begin{array}{l}\downarrow \text { GSH } ; \downarrow \text { TBARs; } \uparrow \text { CAT; } \uparrow \\
\quad \text { GPX }\end{array}$ & $\begin{array}{l}1.25 \mathrm{mg} \text { cadmium chloride } / \mathrm{kg} \text { bw by injection; } \\
1.5 \% \text { green tea extract in drinking water for } \\
45 \text { days }\end{array}$ & $\begin{array}{l}\text { Male } \\
\text { Wistar } \\
\text { rats }\end{array}$ & Liver & $\begin{array}{l}\text { Kumar } \\
\text { et al. } \\
\text { (2010a) }\end{array}$ \\
\hline Green tea & $\begin{array}{l}\downarrow \text { SGOT; } \downarrow \text { SGPT; } \downarrow \text { LDH; } \downarrow \\
\text { GGT }\end{array}$ & $\begin{array}{l}1.25 \mathrm{mg} \text { cadmium chloride } / \mathrm{kg} \text { bw by injection; } \\
1.5 \% \text { green tea extract in drinking water for } \\
45 \text { days }\end{array}$ & $\begin{array}{l}\text { Male } \\
\text { Wistar } \\
\text { rats }\end{array}$ & Blood & $\begin{array}{l}\text { Kumar } \\
\text { et al. } \\
\text { (2010b) }\end{array}$ \\
\hline Green tea & $\uparrow \mathrm{LH} ; \uparrow \mathrm{FSH}$ & $\begin{array}{l}\text { first } 400 \mathrm{mg} \text { cadmium chloride/ } \mathrm{l} \text { distilled water } \\
\text { orally by } 21 \text { days and } 7 \text { or } 14 \mathrm{mg} / \mathrm{l} \text { green tea } \\
\text { solvent through } 21 \text { consecutive days }\end{array}$ & $\begin{array}{l}\text { Female } \\
\text { Wistar } \\
\text { rats }\end{array}$ & Blood & $\begin{array}{l}\text { Mahmood } \\
\text { et al. } \\
\text { (2015) }\end{array}$ \\
\hline Black tea & $\begin{array}{l}\downarrow \mathrm{TG} ; \downarrow \text { LDL; } \uparrow \mathrm{HDL} ; \uparrow \text { liver } \\
\text { structure }\end{array}$ & $\begin{array}{l}1 \mathrm{mg} \text { cadmium chloride/kg bw for } 21 \text { days; } \\
2.5 \% \text { of aqueous solution of black tea extract } \\
\text { orally for } 21 \text { days }\end{array}$ & $\begin{array}{l}\text { Male } \\
\text { Wistar } \\
\text { rats }\end{array}$ & $\begin{array}{l}\text { Liver, } \\
\text { blood }\end{array}$ & $\begin{array}{l}\text { Mantur } \\
\text { et al. } \\
(2014)\end{array}$ \\
\hline $\begin{array}{l}\text { Kombucha } \\
\text { tea }\end{array}$ & $\begin{aligned} & \downarrow \text { AST } ; \downarrow \text { ALT } ; \downarrow \text { ALP; } \uparrow \\
& \text { TAC } ; \uparrow \text { SOD } \uparrow \text { CAT; } \uparrow \\
& \text { GSH } ; \downarrow \text { TBARs } ; \downarrow \text { MDA }\end{aligned}$ & $\begin{array}{l}3.5 \mathrm{mg} \text { cadmium chloride/kg bw by injection } \\
\text { (single dose); kombucha tea ferment during } \\
2 \text { weeks before cadmium chloride injection } \\
\text { and } 4 \text { weeks after injection }\end{array}$ & $\begin{array}{l}\text { Male } \\
\text { albino } \\
\text { rats }\end{array}$ & $\begin{array}{l}\text { Liver, } \\
\text { kidney, } \\
\text { blood }\end{array}$ & $\begin{array}{r}\text { Ibrahim } \\
(2013)\end{array}$ \\
\hline Green tea & $\downarrow \mathrm{MDA} ; \uparrow \mathrm{SOD} ; \uparrow \mathrm{GSH}$ & $\begin{array}{l}4 \mathrm{~g} / \mathrm{l} \text { drinking water cadmium chloride/day } \\
\text { orally for } 8 \text { weeks; } 1.5 \% \text { green tea extract } \\
\text { orally for } 8 \text { weeks }\end{array}$ & $\begin{array}{l}\text { Male } \\
\text { Sprague- } \\
\text { Dawley } \\
\text { rats }\end{array}$ & Testes & $\begin{array}{l}\text { El-Beltagy } \\
\text { et al. } \\
(2015)\end{array}$ \\
\hline
\end{tabular}

$\uparrow$ increased concentration or activity compared to Cd group, $\downarrow$ decreased or inhibited concentration or activity compared to Cd group, $S O D$ superoxide dismutase, $C A T$ catalase, $T A C$ total antioxidant capacity, GPX glutathione peroxidase, $A L P$ alkaline phosphatase, $A C P$ acid phosphatase, $G S H$ glutathione, $T G$ triglicerides, $H D L$ high-density lipoprotein, $L D L$ low-density lipoprotein, $T B A R s$ thiobarbituric acid reactive substances, GGT gamma-glutamyl transferase, MDA malondialdehyde, $L H$ luteinizing hormone, FSH follicle-stimulating hormone, $S G O T$ glutamate oxaloacetate transaminase, $S G P T$ glutamate pyruvate transaminase, $L D H$ lactate dehydrogenase, GGT $\gamma$-glutamyl transferase, $H b$ haemoglobin, $R B C$ red blood cells, $P C V$ packed cell volume, $T L C$ total leucocyte count, $M C V$ mean corpuscular volume, $A L T$ alanine aminotransferase, $A S T$ aspartate aminotransferase, $b w$ body weight

$4 \mathrm{mg} \mathrm{Cd} / \mathrm{kg}$ of body weight for 2 weeks caused an increase in the level of antioxidants in testicles such as: SOD, GPX and GSH (Bu et al. 2011). Renugadevi and Prabu $(2009,2010)$ presented similar results in their studies of blood, liver and kidneys of rats poisoned with $5 \mathrm{mg} \mathrm{Cd} / \mathrm{kg}$ of body weight for 4 weeks,. The rats simultaneously received $50 \mathrm{mg}$ of quercetin. In addition, these authors observed an increase in the level of vitamin $\mathrm{C}$ and $\mathrm{E}$ in the studied organs. Zargar et al. (2015) in addition checked the lipid peroxidation level (LPO), obtaining confirmation that this ratio in the brains of rats receiving quercetin injections (100 $\mathrm{mg} / \mathrm{kg}$ of body weight) was reduced in comparison to the control group. Also, the administration of quercetin $(50 \mathrm{mg} / \mathrm{kg}$ of body weight per day) caused an increase in the antioxidant potential in the kidneys of rats poisoned with $500 \mathrm{mg} \mathrm{Pb} / \mathrm{kg}$ of body weight/day in the form of a water-based solution for 10 weeks, which was manifested in an increased activity of SOD, CAT, GPX and GSH/GSSG (Liu et al. 2010). Similarly, Yuan et al. (2016) found that in the livers of mice poisoned with $0.4 \mathrm{mg} \mathrm{Cd} / \mathrm{kg}$ of body 
Table 3 Effect of tea on an organism exposed simultaneously to $\mathrm{Cd}$ and $\mathrm{Pb}$

\begin{tabular}{|c|c|c|c|c|c|}
\hline Tea & $\begin{array}{l}\text { Protective effect compared } \\
\text { to } \mathrm{Pb} \text { treated animals }\end{array}$ & $\mathrm{Pb}$ and $\mathrm{Cd}$ dose and design & Animals & Target sites & References \\
\hline $\begin{array}{l}\text { Green, } \\
\text { black, } \\
\text { red and } \\
\text { white }\end{array}$ & $\downarrow \mathrm{Cd}$ and $\mathrm{Pb}$ accumulation & $\begin{array}{l}7 \mathrm{mg} \mathrm{Cd} \text { (as cadmium chloride) and } 50 \mathrm{mg} \mathrm{Pb} \\
\text { (as lead acetate)/kg of feed for } 12 \text { weeks; } \\
\text { infusions of teas as a sole source of drink for } \\
12 \text { weeks }\end{array}$ & $\begin{array}{l}\text { Male } \\
\text { Wistar } \\
\text { rats }\end{array}$ & $\begin{array}{l}\text { Femur } \\
\text { bone, } \\
\text { blood }\end{array}$ & $\begin{array}{r}\text { Tomaszewska } \\
\text { et al. (2016) }\end{array}$ \\
\hline $\begin{array}{l}\text { Green, } \\
\text { black, } \\
\text { red and } \\
\text { white }\end{array}$ & $\begin{array}{l}\downarrow \mathrm{Cd} \text { accumulation; } \downarrow \mathrm{Pb} \\
\text { accumulation in liver; } \uparrow \\
\mathrm{SOD} ; \uparrow \mathrm{CAT} ; \uparrow \mathrm{GSH} ; \uparrow \\
\text { GPX }\end{array}$ & $\begin{array}{l}7 \mathrm{mg} \mathrm{Cd} \text { (as cadmium chloride) and } 50 \mathrm{mg} \mathrm{Pb} \\
\text { (as lead acetate)/kg of feed for } 6 \text { and } \\
12 \text { weeks; infusions of teas as a sole source } \\
\text { of drink for } 6 \text { and } 12 \text { weeks }\end{array}$ & $\begin{array}{l}\text { Male } \\
\text { Wistar } \\
\text { rats }\end{array}$ & $\begin{array}{l}\text { Lungs, } \\
\text { brain, } \\
\text { heart, } \\
\text { liver, } \\
\text { kidneys }\end{array}$ & $\begin{array}{l}\text { Winiarska- } \\
\text { Mieczan } \\
(2015)\end{array}$ \\
\hline
\end{tabular}

$\uparrow$ increased concentration or activity compared to $\mathrm{Cd} / \mathrm{Pb}$ group, $\downarrow$ decreased or inhibited concentration or activity compared to $\mathrm{Cd} / \mathrm{Pb}$ group, $S O D$ superoxide dismutase, CAT catalase, GSH glutathione, GPX glutathione peroxidase

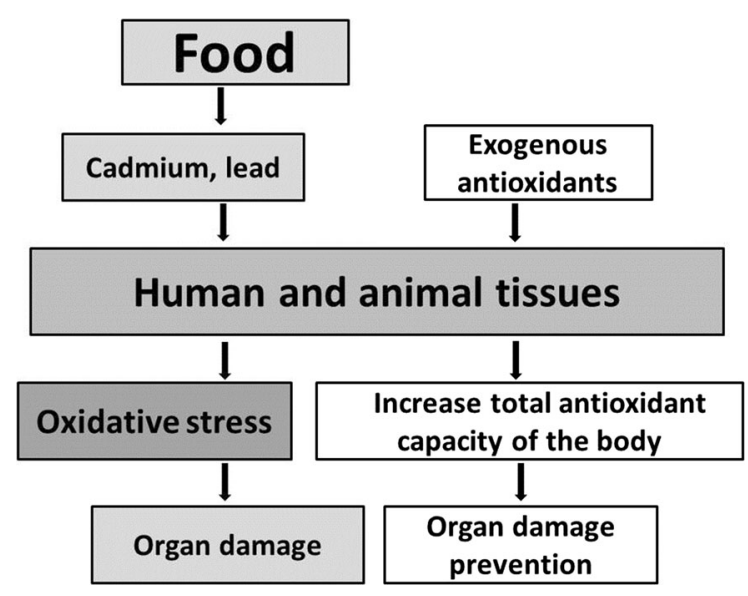

Fig. 2 Efficiency of antioxidants mechanisms resulting from the supply of exogenous antioxidants

weight/day and simultaneously receiving 5-100 mg of quercetin per $\mathrm{kg}$ of body weight per day, the oxidation level of lipids and reactive oxygen species decreased and the total antioxidant capacity increased. In the studies by Nna et al. (2017) female rats were given $5 \mathrm{mg} \mathrm{Cd}\left(\right.$ as $\left.\mathrm{CdCl}_{2}\right)$ per $\mathrm{kg}$ of body weight per day in different combinations: without quercetin (control group) and with $20 \mathrm{mg}$ of quercetin/ $\mathrm{kg}$ of body weight per day $-6 \mathrm{~h}$ before, $6 \mathrm{~h}$ after or simultaneously with cadmium chloride. The uteruses and ovaries of these rats showed an increased antioxidant potential (increase in the activity of SOD, CAT, GPX and GSH level, decrease in MDA and $\mathrm{H}_{2} \mathrm{O}_{2}$ level) compared to the control group. Similar results were presented by Milton Prabu et al. (2013) who in their studies involving rats receiving simultaneously Cd $(50 \mathrm{mg} /$ $\mathrm{kg}$ bw/day) and quercetin ( $5 \mathrm{mg} / \mathrm{kg}$ bw/day) for 4 weeks found an increase in the level of antioxidant parameters in blood and hearts.

In addition, studies were carried out to check the effect of other antioxidants in tea on the antioxidant potential of laboratory animals poisoned with $\mathrm{Cd}$ and/ or $\mathrm{Pb}$ (Table 4). Giving $0.5,1,1.5,2$ or $2.5 \%$ tannic acid solution to rats receiving $7 \mathrm{mg} \mathrm{Cd}$ and $50 \mathrm{mg} \mathrm{Pb} /$ $\mathrm{kg}$ of feed for 6 or 12 weeks increased the activity of SOD and CAT in their brains in comparison to those which were given water to drink (Winiarska-Mieczan 2013). Similarly, Mishra et al. (2015) showed an increase in the antioxidant potential (decreased LPO, increased activity of SOD, CAT and dehydrogenases: isocitrate, alpha-ketoglutaric, succinic and pyruvate dehydrogenase) in rats receiving simultaneously $0.44 \mathrm{mg}$ of cadmium chloride and water-based solutions of tannic acid containing 12, 25 or $50 \mathrm{mg}$ of this substance in comparison to those receiving only $\mathrm{CdCl}_{2}$. Similarly, the use of tannic acid (50 mg per $\mathrm{kg}$ of body weight, 6 times for two weeks) in rats poisoned with lead acetate $(50 \mathrm{mg}$ per $\mathrm{kg}$ of body weight intraperitoneally) intensified the endogenous protection of the body (decreased LPO, increased GSH, GST, GPX, SOD, CAT) in the brains compared to the control group (not receiving tannic acid). Also in livers, kidneys and blood of rats poisoned with $2 \%$ solution of lead acetate for 6 weeks an increase in SOD and CAT was observed in groups receiving polysaccharides isolated from red tea in the amount of 50,100 or $200 \mathrm{mg} / \mathrm{kg}$ of body weight ( $\mathrm{Li}$ and Liu 2014). Wei and Meng (2011) revealed that in the ventricular myocytes of rats poisoned with $\mathrm{Pb}$, the 


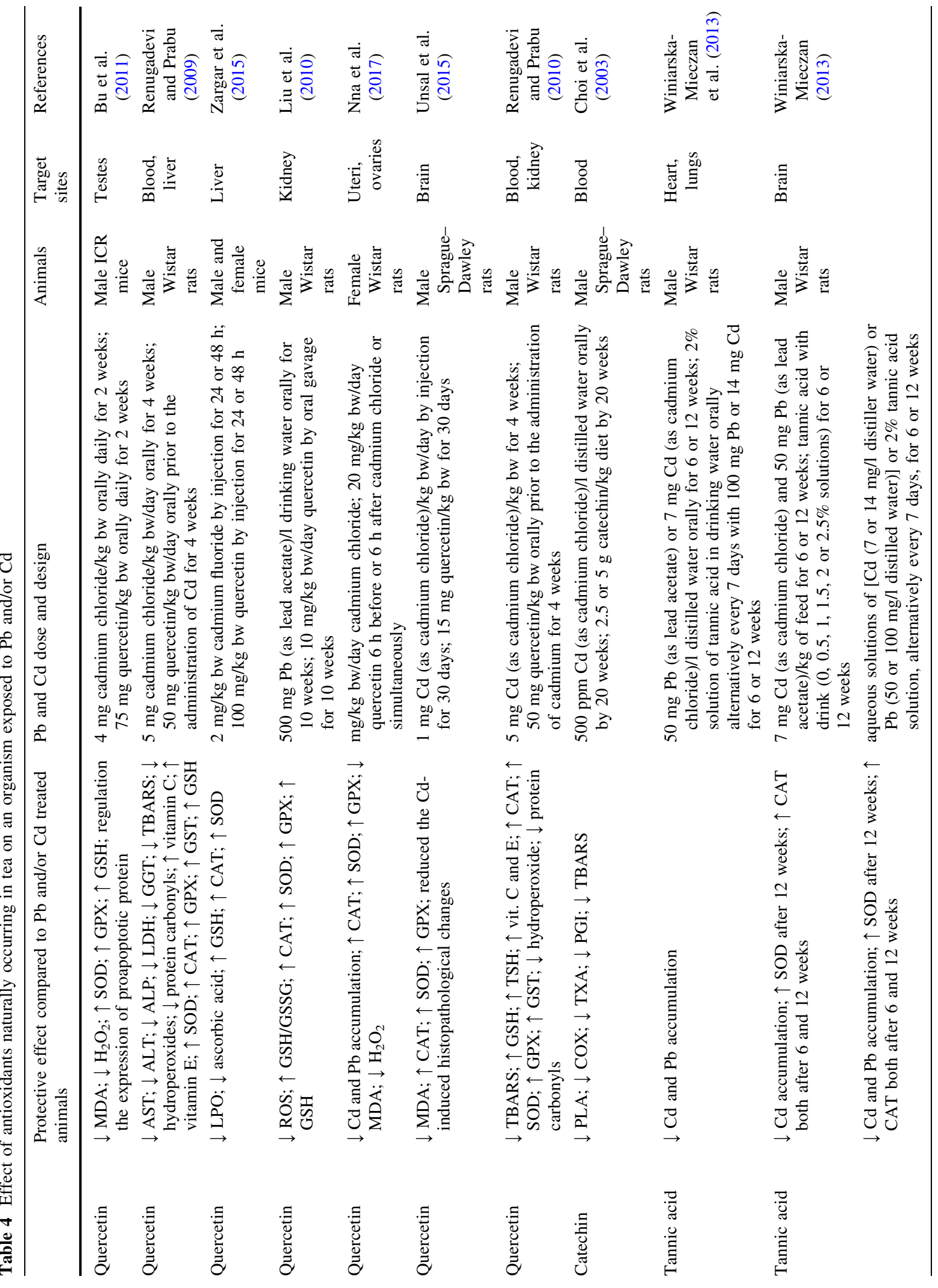




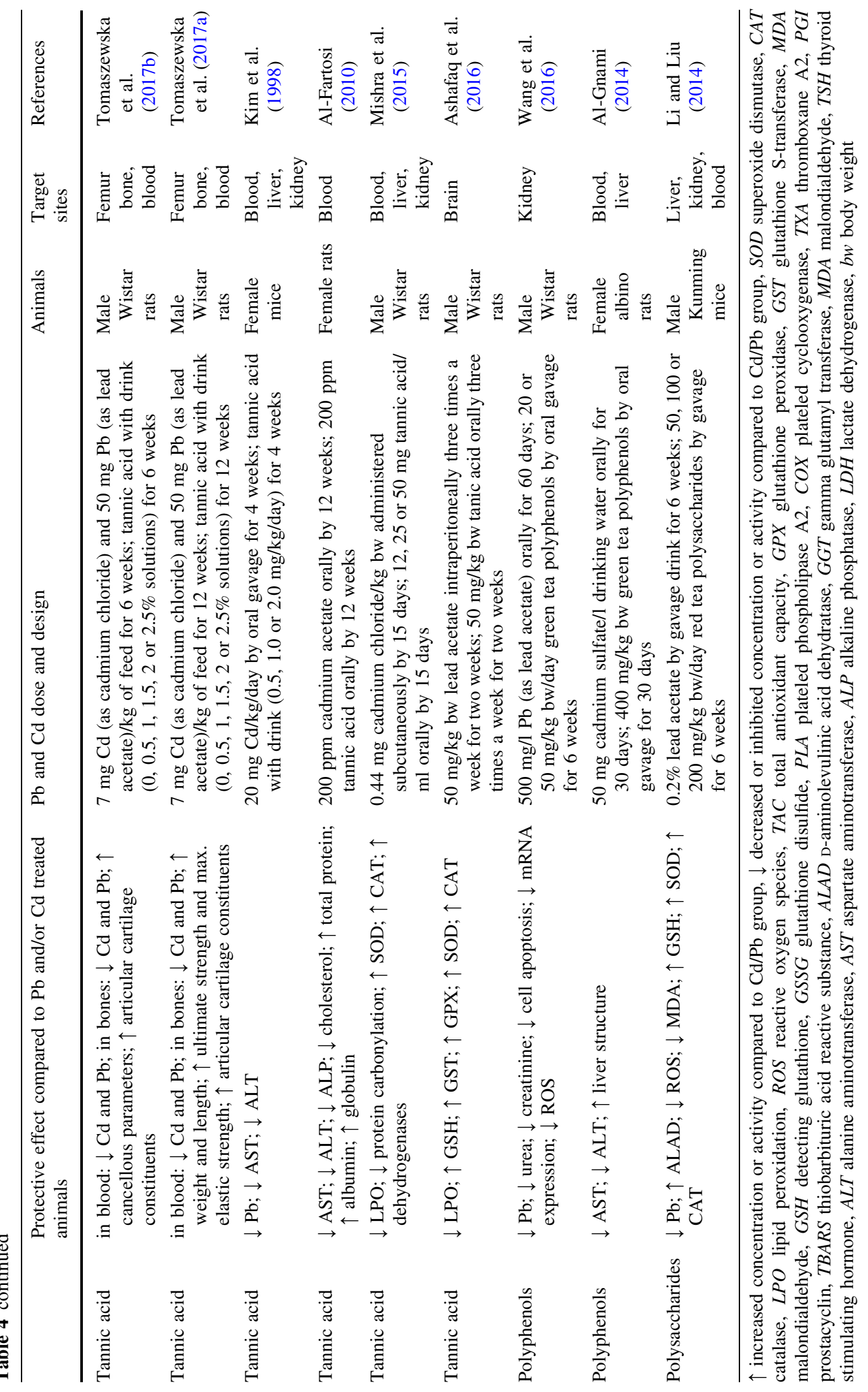


activity of antioxidant ratios after the use of EGCG was increased (increased activity of SOD and CAT, reduction in MDA, $\mathrm{OH} \cdot \mathrm{O}_{2}^{--}$and $\mathrm{H}_{2} \mathrm{O}_{2}$ ).

\section{Chelating effect}

The chelating effect of polyphenols on metals is connected with the content of dihydroxyl and trihydroxyl groups (Khokhar and Owusu Apenten 2003). The effect of chelating is reduced absorption of $\mathrm{Cd}$ and $\mathrm{Pb}$ in tissues.

Tests were performed on rats receiving $\mathrm{Cd}(7 \mathrm{mg} /$ $\mathrm{kg}$ of feed) and $\mathrm{Pb}(50 \mathrm{mg} / \mathrm{kg}$ of feed) in parallel with giving (green, white, black, red) tea infusions to those animals as the only drink for 12 weeks (Tomaszewska et al. 2016; Winiarska-Mieczan 2015). The level of metals was measured in the femoral bone, lungs, heart, liver and kidneys. The results obtained showed the highest effectiveness of reducing the absorption of $\mathrm{Cd}$ and $\mathrm{Pb}$ in the case of a white and green tea solution, while black tea was the least effective. The authors attribute this to the fact that white and green tea contains more polyphenols, including catechins, capable of chelating metallic elements, than in black and red tea (Karori et al. 2007). In the present authors own studies (Winiarska-Mieczan 2015), it was also observed that tea solutions efficiently reduced the degree of accumulation of $\mathrm{Cd}$ in tissues. $\mathrm{Pb}$ was less susceptible to the chelating effect of the ingredients of teas. It was found that, compared to other organs, the teas were the least effective both with regard to $\mathrm{Cd}$ and $\mathrm{Pb}$ in the lungs. This can also suggest that drinking tea will not considerably level, for example, the adverse impact of smoking tobacco that is one of the most important sources of $\mathrm{Cd}$ and $\mathrm{Pb}$ for humans and simultaneously the most important cause of lung cancer (Fowles and Dybing 2003). Polyphenols present in tea reveal strong anticarcinogenic properties (Lambert and Elias 2010), which in this case may not be fully utilized. $\mathrm{Pb}$ is more resistant to the chelating effect of polyphenols than $\mathrm{Cd}$ is since $\mathrm{Pb}$ demonstrates a strong affinity with thiol groups which are absent in polyphenols (Winiarska-Mieczan 2013; Aykin-Burns et al. 2005) but are present in calcium ion transporter protein (Cailliatte et al. 2009), which is the reason for the accumulation of $\mathrm{Pb}$ in bones replacing calcium. The studies revealed that people exposed to $\mathrm{Pb}$ had low levels of calcium but higher concentrations of parathormone (Anetor et al. 2005) responsible for regulating calcium and phosphates (Mudipalli 2007). According to El-Shahat et al. (2009) green tea extract effectively chelates $\mathrm{Cd}$, thanks to which it does not participate in prooxidative processes in the body.

Some authors claim that catechins are the main factor behind inhibiting the absorption of $\mathrm{Cd}$ and $\mathrm{Pb}$ in rats. Studies by Abib et al. (2011) involving mitochondria isolated from the brains of rats showed that EGCG forms inseparable complexes with $\mathrm{Cd}^{2+}$, which prevents their absorption, whereas binding effectiveness was higher at higher $\mathrm{pH}$ values. Paul (2008) and Choi et al. (2003) obtained similar results. However, An et al. (2014) in their studies on human liver cells found that EGCG had a minimum chelating effect on $\mathrm{Cd}^{2+}$. On the other hand, those authors admitted that EGCG facilitated maintaining the redox homeostasis in the analyzed tissues.

Studies revealed that the use of polyphenols isolated from green tea (20 or $50 \mathrm{mg} / \mathrm{kg}$ of body weight/day) in rats poisoned with $500 \mathrm{mg} \mathrm{Pb}$ for 60 days resulted in a significant decrease in the level of $\mathrm{Pb}$ in kidneys compared to the group receiving $\mathrm{Pb}$ only (Wang et al. 2016). In the uteruses and ovaries of female rats receiving $\mathrm{Cd}(5 \mathrm{mg} / \mathrm{kg}$ of body weight per day) and quercetin $6 \mathrm{~h}$ before, $6 \mathrm{~h}$ after or simultaneously with the administration of $\mathrm{Cd}$, the level of $\mathrm{Cd}$ was found to have decreased (Nna et al. 2017). However, based on data available in reference literature, apparently tannic acid is one of the major components of tea determining the preventive effect of tea in relation to $\mathrm{Cd}$ and $\mathrm{Pb}$. Tests involving rats proved that tannic acid reduces the absorption of $\mathrm{Cd}$ and $\mathrm{Pb}$ by tissues, which is a result of the chelating properties of this acid (Winiarska-Mieczan 2013). Kim et al. (1998) demonstrated that the tissues of mice poisoned with $20 \mathrm{mg} \mathrm{Cd}$ per $\mathrm{kg}$ of body weight contained less $\mathrm{Cd}$ if the mice drank a water-based solution containing $0.5,1.0$ or $2.0 \mathrm{mg}$ of tannic acid/ $\mathrm{ml}$. The use of a $2 \%$ tannic acid solution in rats receiving $7 \mathrm{mg} \mathrm{Cd}$ and $50 \mathrm{mg} \mathrm{Pb} / \mathrm{kg}$ of feed or one litre of distilled water contributed to a significant decrease in the accumulation of those toxic metals in the hearts, lungs, tibia and blood compared to rats drinking water (Winiarska-Mieczan et al. 2013; Winiarska-Mieczan 2013; Tomaszewska et al. 2017a, b). Studies showed that $\mathrm{Pb}$ was a more resistant metal than $\mathrm{Cd}$ to being bound by tannic acid (Winiarska-Mieczan 2013), where the use of 0.5, 1 , 1.5 or $2 \%$ tannic acid solutions in adult rats 
simultaneously exposed to $\mathrm{Cd}$ and $\mathrm{Pb}$ resulted in a statistically significant reduction of $\mathrm{Cd}$ absorption in brains by 20-25\% after 6 weeks of the experiment and about $35 \%$ after 12 weeks. However, it had no significant effect on the level of $\mathrm{Pb}$. This could be due to the fact that $\mathrm{Pb}$ reveals a considerably stronger affinity with thiol groups (Aykin-Burns et al. 2005) which do not occur in polyphenolic compounds than with hydroxyl groups present there. In addition, it was found that in rats drinking a tannic acid solution in parallel to receiving feed this substance was more effective than when the solution was administered alternately (every 7 days) with feed contaminated with $\mathrm{Cd}$ and $\mathrm{Pb}$ (Winiarska-Mieczan 2013).

\section{Summary}

To sum up, the protective effect of teas on the body against toxic metals must be considered in the context of the summative effect of various active substances present in infusions, as it cannot be excluded that their simultaneous effect may be different from their effect if used separately and certainly their effect is summative. Thus, it is difficult to determine which antioxidant present in tea infusions has the strongest effect.

Open Access This article is distributed under the terms of the Creative Commons Attribution 4.0 International License (http:// creativecommons.org/licenses/by/4.0/), which permits unrestricted use, distribution, and reproduction in any medium, provided you give appropriate credit to the original author(s) and the source, provide a link to the Creative Commons license, and indicate if changes were made.

\section{References}

Abdel-Maneim HAM, Meki AR, Salem AMA, Mobasher A, Lutfi MF (2014) The protective effect of green tea against lead toxicity in rats kidney. Asian J Biomed Pharm Sci 4:30-34

Abdel-Moneim WM, Ghafeer HH (2007) The potential protective effect of natural honey against cadmium-induced hepatotoxicity and nephrotoxicity. Mansoura J Forensic Med Clin Toxicol 2:75-98

Abib RT, Peres KC, Barbosa AM, Peres TV, Bernardes A, Zimmermann LM, Quincozes-Santos A, Fiedler HD, Leal RB, Farina M, Gottfried C (2011) Epigallocatechin-3gallate protects rat brain mitochondria against cadmiuminduced damage. Food Chem Toxicol 49:2618-2623
Adi PJ, Burra SP, Vataparti AR, Matcha B (2016) Calcium, zinc and vitamin $\mathrm{E}$ ameliorate cadmium-induced renal oxidative damage in albino Wistar rats. Toxicol Rep 3:591-597

Adonaylo VN, Oteiza PI (1999) Lead intoxication: antioxidant defenses and oxidative damage in rat brain. Toxicology 135:77-85

Al-Attar MA (2011) Vitamin E attenuates liver injury induced by exposure to lead, mercury, cadmium and copper in albino mice. Saudi J Biol Sci 18:395-401

Al-Fartosi KG (2010) Tannic acid (TA) protect against cadmium acetate induced toxicity in female rats (role of tannic acid as antioxidant). J Thi-Quar Sci 2:216-226

Al-Gnami SA (2014) Effect of polyphenols which extracted from green tea in reduce toxic effects of cadmium sulfate in rat's liver. IOSR J Pharm Biol Sci 9:53-58

Ambrożewicz E, Zapora E, Szczepaniak M, Wnuczko K, Dziakowska I, Skrzydlewska E (2010) Comparison of black and green tea effect on endothelial cells. Bromat Chem Toksykol 1:66-72

Amić A, Lučić B, Stepanić V, Marković Z, Marković S, Dimitrić Marković JM, Amić D (2017) Free radical scavenging potency of quercetin catecholic colonic metabolites: thermodynamics of $2 \mathrm{H}^{+} / 2 \mathrm{e}^{-}$processes. Food Chem 218:144-151

Amorati R, Baschieri A, Cowden A, Valgimigli L (2017) The antioxidant activity of quercetin in water solution. Biomimetics 2:9. https://doi.org/10.3390/ biomimetics 2030009

An Z, Qi T, Huang D, Gu X, Tian Y, Li P, Li H, Zhang Y (2014) EGCG inhibits $\mathrm{Cd}^{2+}$-induced apoptosis through scavenging ROS rather than chelating $\mathrm{Cd}^{2+}$ in HL-7702 cells. Toxicol Mech Methods. https://doi.org/10.3109/15376516. 2013.879975

Anetor JI, Akingbola TS, Adeniyi FAA, Taylor GO (2005) Decreased total and ionized calcium levels and hematological indices in occupational lead exposure as evidence of the endocrine disruptive effect of lead. Indian J Occup Environ Med 9:15-21

Ashafaq M, Tabassum H, Vishnoi S, Salman M, Raisuddin S, Parvez S (2016) Tannic acid alleviates lead acetate-induced neurochemical perturbations in rat brain. Neurosci Lett 617:94-100

Awoniyi DO, Aboua YG, Marnewick JL, du Plesis SS, Brooks NL (2011) Protective effects of rooibos (Aspalathus linearis), green tea (Camellia sinensis) and commercial supplements on testicular tissue of oxidative stress-induced rats. Afr J Biotechnol 10:17317-17322

Aykin-Burns N, Franklin EA, Ercal N (2005) Effects of $\mathrm{N}$-acetylcysteine on lead-exposed PC-12 cells. Arch Environ Contam Toxicol 49:119-123

Bailey RG, Nursten HE, Mcdowell I (1994) Isolation and highperformance liquid chromatographic analysis of thearubigin fractions from black tea. J Chromatogr A 662:101-112

Bharadwaz A, Bhattacharjee C (2012) Extraction of polyphenols from dried tea leaves. J Sci Eng Res 3:1-5

Bu T, Mi Y, Zeng W, Zhang Q (2011) Protective effect of quercetin on cadmium-induced oxidative toxicity on germ cells in male mice. Anat Rec 294:520-526 
Cailliatte R, Lapeyre B, Briat JF, Mari S, Curie C (2009) The NRAMP6 metal transporter contributes to cadmium toxicity. Biochem J 422:217-228

Chen W, Sun S, Cao W, Liang Y, Song J (2009) Antioxidant property of quercetin-Cr(III) complex: the role of $\mathrm{Cr}$ (III) ion. J Mol Struct 918:194-197

Choi JH, Rhee IK, Park KY, Park KY, Kim JK, Rhee SJ (2003) Action of green tea catechin on bone metabolic disorder in chronic cadmium-poisoned rats. Life Sci 73:1479-1489

Choung MG, Hwang YS, Lee MS, Lee J, Kang ST, Jun TH (2013) Comparison of extraction and isolation efficiency of catechins and caffeine from green tea leaves using different solvent systems. Int J Food Sci Technol 49:1572-1578

Chung HY, Yokozawa T, Soung DY, Kye IS, No JK, Beak BS (1998) Peroxynitrite-scavenging activity of green tea tannin. J Agric Food Chem 46:4484-4486

Czeczot H, Ścibior-Bentkowska D, Skrzycki M, Podsiad M, Karlik W, Bąkała A, Grono D, Wiechetek M (2009) Effect of cadmium on the activity of antioxidant enzymes in isolated rat hepatocytes. Medycyna Wet 65:55-60

Dalle-Donne I, Milzani A, Gagliano N, Colombo R, Giustarini D, Rossi R (2008) Molecular mechanisms and potential clinical significance of S-glutathionylation. Antioxid Redox Signal 10:445-473

Dolinoy DC, Weidman JR, Waterland RA, Jirtle RL (2006) Maternal genistein alters coat color and protects Avy mouse offspring from obesity by modifying the fetal epigenome. Environ Health Perspect 114:567-572

Donejko M, Niczyporuk M, Galicka E, Przylipiak A (2013) Anti-cancer properties epigallocatechin-gallate contained in green tea. Postepy Hig Med Dosw 67:26-34

EFSA (2012a) Cadmium dietary exposure in the European population. EFSA J 10:2551. https://doi.org/10.2903/j. efsa.2012.2551

EFSA (2012b) Lead dietary exposure in the European population. EFSA J 10:2831. https://doi.org/10.2903/j.efsa.2012. 2831

El Kader MAA, El-Sannad NM, Taha H (2012) The protective role of rosemary (Rosmarinus officinalis) in lead acetate induced toxicity in rats. J Appl Sci Res 8:3071-3082

El-Beltagy MA, Saleh SY, El-Ghannam AER, Ibrahim IA (2015) Protective effect of green tea extract on heavy metals-induced oxidative testicular damage in rats. Indian J Appl Res 5:577-583

El-Sayed NS, Rizk SM (2009) The protective effect of quercetin, green tea or malt extracts against experimentallyinduced lung fibrosis in rats. Afr J Pharm Pharmacol 3:191-201

El-Shahat AER, Gabr A, Meki AR, Mehana ES (2009) Altered testicular morphology and oxidative stress induced by cadmium in experimental rats and protective effect of simultaneous green tea extract. Int J Morphol 27:757-764

El-Ziney MG, Shokery ES, Youssef AH, Mashaly RE (2017) Protective effects of green tea and moringa leave extracts and their bio-yogurts against oxidative effects of lead acetate in albino rats. J Nutrit Health Food Sci 5:1-11

Ercal N, Gurer H, Aykin Burns N (2001) Toxic metals and oxidative stress. Part I: mechanisms involved in metal-induced oxidative damage. Curr Top Med Chem 1:529-539

Essa TM, Mehana SED, Meki ARM (2009) Histological and biochemical changes in the testis of rats exposed to lead: protective effect of green tea extract. Asian Acad Manag J $7: 18$

Flora SJS, Mittal M, Mehta A (2008) Heavy metal induced oxidative stress \& its possible reversal by chelation therapy. Indian J Med Res 128:501-523

Fowler BA, Whittaker MH, Lipsky M, Wang G, Chen XQ (2004) Oxidative stress induced by lead, cadmium and arsenic mixtures: 30-day, 90-day, and 180-day drinking water studies in rats: an overview. Biometals 17:567-568

Fowles J, Dybing E (2003) Application of toxicological risk assessment principles to the chemical constituents of cigarette smoke. Tob Control 12:424-430

Fujiwara C, Imamura A, Hashiguchi N, Shimozawa N, Suzuki Y, Kondo N, Imanaka T, Tsukamoto T, Osumi T (2000) Catalase-less peroxisomes. J Biol Chem 275:37271-37277

Gawlik M, Czajka A (2007) The effect of green, black and white tea on the level of $\alpha$ and $\gamma$ tocopherols in free radicalinduced oxidative damage of human red blood cells. Acta Pol Pharm 64:159-164

Gramza A, Korczak J, Amarowicz R (2005) Tea polyphenolstheir antioxidant properties and biological activity-a review. Pol J Food Nutr Sci 14(55):219-235

Gülcin I, Huyut Z, Elmastas M, Aboul-Enein HY (2010) Radical scavenging and antioxidant activity of tannic acid. Arab J Chem 3:43-53

Hamadouche NA, Guellil H, Slimani M, Aoues A (2014) Positive effects of green tea (Camelia sinensis) on hepatic dysfunction induced by lead acetate in male rats. Int J Drug Dev Res 6:87-96

Hamadouche NA, Lazeb H, Kaddouri A, Guellil H, Slimani M, Aoues A (2015) Ameliorated effects of green tea extract on lead induced kidney toxicity in rats. Alger J Natur Prod 3:130-137

Hamden K, Carreau S, Ellouz F, Masmoudi H, El Feki A (2009) Improvement effect of green tea on hepatic dysfunction, lipid peroxidation and antioxidant defence depletion induced by cadmium. Afr J Biotechnol 8:4233-4238

Hamed EA, Meki ARMA, Abd El-Mottaleb NA (2010) Protective effect of green tea on lead-induced oxidative damage in rat's blood and brain tissue homogenates. J Physiol Biochem 66:143-151

Hicks A (2009) Current status and future development of global tea production and tea products. AU J Technol 12:251-264

Ibrahim NK (2013) Possible protective effect of kombucha tea ferment on cadmium chloride induced liver and kidney damage in irradiated rats. Int J Biol Life Sci 9:7-12

Ighodaro OM, Akinloyeb OA (2017) First line defence antioxidants-superoxide dismutase (SOD), catalase (CAT) and glutathione peroxidase (GPX): their fundamental role in the entire antioxidant defence grid. Alex J Med. https://doi. org/10.1016/j.ajme.2017.09.001

Jaishankar M, Tseten T, Anbalagan N, Mathew BB, Beeregowda KN (2014) Toxicity, mechanism and health effects of some heavy metals. Interdiscip Toxicol 7:60-72

Karori SM, Wachira FN, Wanyoko JK, Ngure RM (2007) Antioxidant capacity of different types of tea products. Afr J Biotechnol 6:2287-2296

Khalaf AA, Moselhy WA, Abdel-Hamed MI (2012) The protective effect of green tea extract on lead induced oxidative and DNA damage on rat brain. Neurotoxicology 33:280-289 
Khokhar S, Owusu Apenten RK (2003) Iron binding characteristics of phenolic compounds: some tentative structureactivity relations. Food Chem 81:133-140

Kim PG, Ahn RM, Hwang SH (1998) The effects of tannic acid to the cadmium on mouse. J Fd Hyg Safety 13:87-93

Kim HS, Quon MJ, Kim J (2014) New insights into the mechanisms of polyphenols beyond antioxidant properties; lessons from the green tea polyphenol, epigallocatechin 3-gallate. Redox Biol 2:187-195

Kobylińska A, Janas KM (2015) Health-promoting effect of quercetin in human diet. Postepy Hig Med Dosw 69:51-62

Kono Y, Fridovich I (1982) Superoxide radical inhibits catalase. J Biol Chem 257:5751-5754

Korir MW, Wachira FN, Wanyoko JK, Ngure RM, Khalid R (2014) The fortification of tea with sweeteners and milk and its effect on in vitro antioxidant potential of tea product and glutathione levels in an animal model. Food Chem 145:145-153

Kuhnert N (2010) Unraveling the structure of the black tea thearubigins. Arch Biochem Biophys 501:37-51

Kumar PV, Bricey AA, Selvi VVT, Kumar CS, Ramesh N (2010a) Antioxidant effect of green tea extract in cadmium chloride intoxicated rats. Adv Appl Sci Res 1:9-13

Kumar PV, Pricy AA, Kumar ChS, Kumar GK (2010b) Hepatoprotective effect of green tea (Camelia sinensis) on cadmium chloride induced toxicity in rats. J Chem Pharm Res 2:125-128

Kusano R, Matsuo Y, Sato Y, Tanaka T (2015) Oxidation mechanism of black tea pigment theaflavin by peroxidase. Tetrah Lett 56:5099-5102

Lambert JD, Elias RJ (2010) The antioxidant and pro-oxidant activities of green tea polyphenols: a role in cancer prevention. Arch Biochem Biophys 501:65-72

Leenen R, Roodenburg AJ, Tijburg LB, Wiseman SA (2000) A single dose of tea with or without milk increases plasma antioxidant activity in humans. Europ J Clin Nutr 54:87-92

Leung LK, Su Y, Chen R, Zhang Z, Kuang Y, Chen ZY (2001) Theaflavins in black tea and catechins in green tea are equally effective antioxidants. J Nutr 131:2248-2251

Li XK, Liu FL (2014) Protective effect of crude polysaccharide from Xinyang red tea against lead toxicity. Biotechnology 10:12187-12192

Li S, Yan T, Yang JQ, Oberley TD, Oberley LW (2000) The role of cellular glutathione peroxidase redox regulation in the suppression of tumor cell growth by manganese superoxide dismutase. Cancer Res 60:3927-3939

Liczmański A (1988) Oxygen toxicity. I: damage of living cells. Post Biochem 34:273-291

Liu CM, Ma JQ, Sun YZ (2010) Quercetin protects the rat kidney against oxidative stress-mediated DNA damage and apoptosis induced by lead. Environ Toxicol Pharmacol 30:264-271

MacMillan-Crow LA, Crow JP, Thompson JA (1998) Peroxynitrite-mediated inactivation of manganese superoxide dismutase involves nitration and oxidation of critical tyrosine residues. Biochemistry 37:1613-1622

Mahmood B, Mokhtar M, Esfandiar S (2015) The impact of green tea (Camelia sinensis) on the amount of gonadotropin hormones (LH, FSH) in immature female rats poisoned with cadmium chloride. Biomed Pharmacol J $8: 261-268$
Mantur VS, Somannavar MS, Yendigeri S, Das KD, Goudar SS (2014) Ameliorating effect of black tea extract on cadmium chloride-induced alteration of serum lipid profile and liver histopathology in rats. Indian $\mathrm{J}$ Physiol Pharmacol 58:128-132

Mao T, Han C, Wei B, Zhao L, Zhang Q, Deng R, Liu J, Luo Y, Zhang Y (2018) Protective effects of quercetin against cadmium chloride-induced oxidative injury in goat sperm and zygotes. Biol Trace Elem Res. https://doi.org/10.1007/ s12011-018-1255-8

Mehana E, Meki AR, Fazili KM (2012) Ameliorated effects of green tea extract on lead induced liver toxicity in rats. Exp Toxicol Pathol 64:291-295

Meki AR, Alghasham A, El-Deeb ES (2011) Effect of green tea extract on lead toxicity in different organs of rats. Int $\mathbf{J}$ Health Sci (Quassim) 5:12-15

Menet MC, Sang S, Yang CS, Ho CT, Rosen RT (2004) Analysis of theaflavins and thearubigins from black tea extract by MALDI-TOF mass spectrometry. J Agric Food Chem 52:2455-2461

Michalak-Majewska M (2011) Properties of tea. Part 1: nutritional importance. Nauka Przyr Technol 5(6):114. http:// www.npt.up-poznan.net/tom5/zeszyt6/art_114.pdf

Milton Prabu S, Muthumani M, Shagirtha K (2013) Quercetin potentially attenuates cadmium induced oxidative stress mediated cardiotoxicity and dyslipidemia in rats. Eur Rev Med Pharmacol Sci 17:582-595

Mirani N, Nagma AJ, Siddique J, Rub A (2012) Protective effect of rutin against cadmium induced hepatotoxicity in Swiss albino mice. J Pharmacol Toxicol 7:150-157

Mishra S, Ghosh D, Dutta M, Chattopadhyay A, Bandyopadhyay D (2015) Tannic acid protects against cadmium-induced renal damages of male albino rats. Int J Pharm Sci Rev Res 32:273-281

Mudipalli A (2007) Lead hepatotoxicity and potential health effects. Indian J Med Res 126:518-527

Nemmiche S (2017) Oxidative signaling response to cadmium exposure. Toxicol Sci 156:4-10

Nna VU, Usman UZ, Ofulet EO, Owu DU (2017) Quercetin exerts preventive, ameliorative and prophylactic effects on cadmium chloride-induced oxidative stress in the uterus and ovaries of female Wistar rats. Food Chem Toxicol 102:143-155

Ohmori R, Iwamato T, Tago M, Takeo T, Unno T, Itakura H, Kondo K (2005) Antioxidant activity of various teas against free radical and LDL oxidation. Lipids 40:849-853

Padalko VI, Kozlova E, Leonova I (2012) Protective efficacy of garlic on cadmium induced oxidative stress in young and adult rats. Oxid Antioxid Med Sci 1:101-109

Patra RC, Rautray AK, Swarup D (2011) Oxidative stress in lead and cadmium toxicity and its amelioration. Vet Med Int 27:18-19. https://doi.org/10.4061/2011/457327

Paul DH (2008) Effect of green tea polyphenols on cadmium toxicity in rats. Dominic Educ J 6:1-10

Pereira RB, Sousa C, Costa A, Andrade PB, Valentão P (2013) Glutathione and the antioxidant potential of binary mixtures with flavonoids: synergisms and antagonisms. Molecules 18:8858-8872

Pourahmad J, O'Brien PJ (2000) A comparison of hepatocyte cytotoxic mechanisms for $\mathrm{Cu}^{2+}$ and $\mathrm{Cd}^{2+}$. Toxicol 143:263-273 
Puerto-Parejo LM, Aliaga I, Canal-Macias ML, Leal-Hernandez O, Roncero-Martín R, Rico-Martín S, Moran JM (2017) Evaluation of the dietary intake of cadmium, lead and mercury and its relationship with bone health among postmenopausal women in Spain. Int J Environ Res Public Health 14:564. https://doi.org/10.3390/ijerph14060564

Pulido R, Bravo L, Saura-Calixto F (2000) Antioxidant activity of dietary polyphenols as determined by a modified ferric reducing/antioxidant power assay. J Agric Food Chem 48:3396-3402

Ramesh B, Satakopan VN (2010) Antioxidant activities of hydroalcoholic extract of Ocimum sanctum against cadmium induced toxicity in rats. Ind $\mathrm{J}$ Clin Biochem 25:307-310

Renugadevi J, Prabu SM (2009) Ameliorative effect of quercetin against cadmium induced toxicity in liver of Wistar rats. J Cell Tissue Res 9:1665-1672

Renugadevi J, Prabu SM (2010) Quercetin protects against oxidative stress-related renal dysfunction by cadmium in rats. Exp Toxicol Pathol 62:471-481

Rietveld A, Wiseman S (2003) Antioxidant effects of tea: evidence from human clinical trials. J Nutr 133:3285-3292

Rubino FM (2015) Toxicity of glutathione-binding metals: a review of targets and mechanisms. Toxics 3:20-62

Sánchez-Moreno C, Jiménez-Escrig A, Saura-Calixto F (2000) Study of low-density lipoprotein oxidizability indices to measure the antioxidant activity of dietary polyphenols. Nutr Res 20:941-953

Savolainen H (1992) Tannin content of tea and coffee. J Appl Toxicol 12:191-192

Schützendübel A, Polle A (2002) Plant responses to abiotic stresses: heavy metal-induced oxidative stress and protection by mycorrhization. J Exp Bot 53:1351-1365

Serafini M, Ghiselli A, Ferro Luzzi A (1996) In vivo antioxidant effect of green and black tea in man. Eur $\mathrm{J}$ Clin Nutr 50:28-32

Singh N, Rani P, Gupta M, Goel N, Tandan N (2013a) Effects of aqueous extract of Camellia sinensis (L.) O. kuntze on liver markers of cadmium treated rats. J Biotechnol Pharm Res 4:89-93

Singh N, Rani P, Gupta M, Tandan N (2013b) Role of green tea on cadmium toxicity on haematological profile of albino rats. Am J Phytomed Clin Therap 1:537-542

Skoczyńska A (1997) Lipid peroxidation as a toxic model of action for lead and cadmium. Med Pr 48:197-203

Stohs SJ, Bagchi D (1995) Oxidative mechanisms in the toxicity of metal ions. Free Radic Biol Med 18:321-336

Sung H, Nah J, Chun S, Park H, Yang SE, Min WK (2000) In vivo antioxidant effect of green tea. Eur J Clin Nutr 54:527-529

Tandon SK, Singh S, Prasad S, Khandekar K, Dwivedi VK, Chatterjee M, Mathur N (2003) Reversal of cadmium induced oxidative stress by chelating agent, antioxidant or their combination in rats. Toxicol Lett 145:211-217

Tarasub N, Junseecha T, Tarasub Ch, Ayutthaya WDN (2012) Protective effects of curcumin, vitamin $\mathrm{C}$, or their combination on cadmium-induced hepatotoxicity. J Basic Clin Pharm 3:273-281

Tian L, Cai Q, Wei H (1998) Alterations of antioxidant enzymes and oxidative damage to macromolecules in different organs of rats during aging. Free Radic Biol Med 24:1477-1484

Tomaszewska E, Dobrowolski P, Winiarska-Mieczan A, Kwiecień M, Tomczyk A, Muszyński S, Radzki R (2016) Alteration in bone geometric and mechanical properties, histomorphometrical parameters of trabecular bone, articular cartilage and growth plate in adolescent rats after chronic co-exposure to cadmium and lead in the case of supplementation with green, black, red and white tea. Environ Toxicol Pharmacol 46:36-44

Tomaszewska E, Dobrowolski P, Winiarska-Mieczan A, Kwiecień M, Tomczyk A, Muszyński S (2017a) The effect of tannic acid on the bone tissue of adult male Wistar rats exposed to cadmium and lead. Exp Toxicol Pathol 69:131-141

Tomaszewska E, Dobrowolski P, Winiarska-Mieczan A, Kwiecień M, Muszyński Ś, Tomczyk A (2017b) The effect of tannic acid on bone mechanical and geometric properties, bone density, and trabecular histomorphometry as well as the morphology of articular and growth cartilages in rats co-exposed to cadmium and lead is dose dependent. Toxicol Ind Health 33:855-866

Toschi TG, Bordoni A, Hrelia S, Bendini A, Lercker G, Biagi PL (2000) The protective role of different green tea extracts after oxidative damage is related to their catechin composition. J Agric Chem 48:3973-3978

Unsal C, Kanter M, Aktas C, Erboga M (2015) Role of quercetin in cadmium-induced oxidative stress, neuronal damage, and apoptosis in rats. Toxicol Ind Health 31:1106-1115

Valko M, Rhodes CJ, Moncol J, Izakovic M, Mazur M (2006) Free radicals, metals and antioxidants in oxidative stressinduced cancer. Chem Biol Interact 160:1-40

Waisberg M, Joseph P, Hale B, Beyersmann D (2003) Molecular and cellular mechanisms of cadmium carcinogenesis. Toxicology 192:95-117

Wang H, Li D, Hu Z, Zhao S, Zheng Z, Li W (2016) Protective effects of green tea polyphenol against renal injury through ROS-mediated JNK-MAPK pathway in lead exposed rats. Moll Cell 39:508-513

Wei H, Meng Z (2011) Protective effect of epigallocatechin-3gallate against lead-induced oxidative damage. Hum Exp Toxicol 30:1521-1528

Winiarska-Mieczan A (2013) Protective effect of tannic acid on the brain of adult rats exposed to cadmium and lead. Environ Toxicol Pharmacol 36:9-18

Winiarska-Mieczan A (2014) Cumulative rate and distribution of $\mathrm{Cd}$ and $\mathrm{Pb}$ in the organs of adult male Wistar rats during oral exposure. Environ Toxicol Pharmacol 38:751-760

Winiarska-Mieczan A (2015) The potential protective effect of green, black, red and white tea infusions against adverse effect of cadmium and lead during chronic exposure-a rat model study. Regul Toxicol Pharmacol 73:521-529

Winiarska-Mieczan A, Krusiński R, Kwiecień M (2013) Tannic acid influence on lead and cadmium accumulation in the hearts and lungs of rats. Adv Clin Exp Med 22:615-620

Wołonciej M, Milewska E, Roszkowska-Jakimiec W (2016) Trace elements as an activator of antioxidant enzymes. Postepy Hig Med Dosw (Online) 70:1483-1498

Wołosiak R, Mazurkiewicz M, Drużyńska B, Worobiej E (2008) Antioxidant activity of the selected green teas. Żywn Nauka Technol Jakość 4:290-297 
Wu Y, Li W, Xu Y, Jin E, Tu Y (2011) Evaluation of the antioxidant effects of four main theaflavin derivatives through chemiluminescence and DNA damage analyses. J Zhejiang Univ Sci B 12:744-747

Xu JZ, Yeung SVY, Chang Q, Huang Y, Chen Z-Y (2004) Comparison of antioxidant activity and bioavailability of tea epicatechins with their epimers. Brit J Nutr 91:873-881

Yosef TA, Al-Julaifi MZ, Kandeel M (2012) The effects of green tea (Camelia sinensis) probiotics on broilers exposed to lead-induced oxidative stress. J Am Sci 8:499-506

Yoshino K, Hara Y, Sano M, Tomita S (1994) Antioxidative effects of black tea theaflavins and thearubigin on lipid perioxidation of rat liver homogenates induced by tertbutyl hydroperoxide. Biol Pharm Bull 17:146-149
Yuan Y, Ma S, Qi Y, Wei X, Cai H, Dong L, Lu Y, Zhang Y, Guo Q (2016) Quercetin inhibited cadmium-induced autophagy in the mouse kidney via inhibition of oxidative stress. J Toxicol Pathol 29:247-252

Zargar S, Siddiqi NJ, Al Daihan SK, Wani T (2015) Protective effects of quercetin on cadmium fluoride induced oxidative stress at different intervals of time in mouse liver. Acta Biochim Pol 62:207-213

Zaveri NT (2006) Green tea and its polyphenolic catechins: medicinal uses in cancer and noncancer applications. Life Sci 78:2073-2080

Zhu J, Filippich LJ, Alsalam MT (1992) Tannic acid intoxication in sheep and mice. Res Vet Sci 53:280-292 